\title{
OPTIMIZATION OF LIGNIN EXTRACTION FROM RICE HUSK BY ALKALINE HYDROGEN PEROXIDE USING RESPONSE SURFACE METHODOLOGY
}

\author{
Anwar Ma'ruf ${ }^{1,2}$, Bambang Pramudono ${ }^{2, *}$ and Nita Aryanti ${ }^{2}$ \\ ${ }^{1}$ Department of Chemical Engineering, Universitas Muhammadiyah Purwokerto, J1. Raya Dukuh \\ Waluh, Kembaran, Purwokerto, Indonesia, 53182 \\ ${ }^{2}$ Department of Chemical Engineering, Diponegoro University, J1. Prof. Soedharto, Tembalang, \\ Semarang, Jawa Tengah, Indonesia 50239 \\ *E-mail: pramudonoundip@gmail.com
}

\begin{abstract}
Lignin is a natural polymer consisting of three major phenylpropanoid monomers (coniferyl alcohol (G), sinapyl alcohol $(\mathrm{S})$ and pcoumaryl alcohol $(\mathrm{H})$ ). Lignin from biomass can be extracted by several solvents. This research studied the extraction of lignin from rice husk using an alkaline hydrogen peroxide. Three variables of extraction process comprising solvent to solid ratio, hydrogen peroxide concentration and $\mathrm{pH}$ of the mixture were studied. Response surface methodology with the central composite design was used to optimize the process variables. The optimum conditions for lignin extraction from rice husk using alkaline hydrogen peroxide were found at the solvent to solid ratio of 8.55 , the $\mathrm{H}_{2} \mathrm{O}_{2}$ concentration of $1.56 \%$ and $\mathrm{pH}$ of 11.26 . At this condition, the amount of lignin extracted was $1.7939 \%$. Rice husk lignin obtained has similar characteristics with the lignin from another biomass source. However, based on FT-IR spectra, the specific characterization of rice husk lignin was found at the band of 2360.78 and $2075.41 \mathrm{~cm}^{-1}$. The band between 2100 and $2360 \mathrm{~cm}^{-1}$ is a typical $\mathrm{Si}-\mathrm{H}$ bond.
\end{abstract}

Keywords: Rice husk, rice husk lignin, alkaline hydrogen peroxide, response surface methodology

(C) RASĀYAN. All rights reserved

\section{INTRODUCTION}

Lignin is an amorphous polyphenolic lignocellulosic material, consists of three major phenylpropanoid monomers (coniferyl alcohol (G), sinapyl alcohol (S) and pcoumaryl alcohol(H)) forming a 3dimensional network inside the cell wall of biomass ${ }^{1}$. Lignin is a raw material for bio-products and bio-fuel. There are several methods for extraction of lignin from biomass. Alkali and acid solvent are the common methods for lignin extraction ${ }^{2}$. Utilization of alkali and acid solvent have disadvantages such as low purity and exhibited the lowest yields. In the recent works, some researchers applied several solvents to increase yield and purity of lignin extracted. There were several categories of solvents for lignin extraction such as organic solvent (organosolv) $)^{3-6}$, ionic solvent ${ }^{5,7}$, oxidative solvent ${ }^{8,9}$ and hot water. ${ }^{10-13}$ The selection of solvent is an important factor to the process of extraction of lignin from biomass.

Alkaline hydrogen peroxide (AHP) is an oxidative solvent. The AHP solvent is effective enough to raise the yield of lignin ${ }^{9}$. Hydrogen peroxide is a green oxidant that breaks the bond in lignin under alkaline conditions. Hydrogen peroxide is unstable under alkaline conditions and easily decomposes to more active radicals, such as hydroxyl radicals $\left(\mathrm{OH}^{*}\right)$ and superoxide anion radicals $\left(\mathrm{OO}^{\circ}\right)$, which influence in the lignin extraction ${ }^{14}$. Many factors such as the solvent to solid ratio, solvent composition, extraction time, extraction temperature and $\mathrm{pH}$ of the solution may significantly have an effect on the AHP extraction yield. Optimization of variables is necessary to determine the optimum condition. The common method for variables optimization of the extraction process is Response Surface Methodology (RSM). ${ }^{15-19}$ Rice husk has specific characteristics. Besides its high content of lignin, the rice husk lignin also has high silica content.$^{20}$ It means that in the process of lignin extraction, silica will be extracted. Therefore, the purification process of lignin from silica impurities becomes an important factor. In the previous studies, 
the silica extracted in the process of lignin extraction from rice husk has not intensely been investigated..$^{3-}$ 4,21

The aims of this research are to determine the optimum condition of lignin extraction and describe silica extracted base on liquor concentration. Three process variables comprising solvent to solid ratio, the concentration of hydrogen peroxide and $\mathrm{pH}$ of the solution are evaluated. The RSM with central composite design (CCD) is applied to optimize the process variables of extraction. The CCD was effectively used to optimize the variables process. ${ }^{22-24}$

\section{Materials}

\section{EXPERIMENTAL}

Rice husk was purchased from a local rice milling factory at Banyumas, Jawa Tengah, Indonesia. Rice husk was crushed to mesh size of $40-60$ and dried at $60^{\circ} \mathrm{C}$ for 6 hours. Hydrogen peroxide solution (30\%), sulfuric acid and sodium hydroxide were obtained from Merck. Demineralized water was produced by ELVA-VEOLIA water demineralized.

\section{Isolation Process}

Lignin isolation process was performed by using an alkaline hydrogen peroxide solution. A total of 20 grams of rice husk was inserted into the $500 \mathrm{ml}$ flask and then added $180 \mathrm{~mL}$ demineralized water containing $1.5 \% \mathrm{H}_{2} \mathrm{O}_{2}$ with the ratio of volume/weight of $9: 1$. The mixture was added by a $2 \mathrm{~N} \mathrm{NaOH}$ until $\mathrm{pH}$ of 11 was achieved. The mixture was then isolated at the temperature of $100^{\circ} \mathrm{C}$ by using the heating oil bath for 3 hours starting after the temperature reached $100^{\circ} \mathrm{C}$. After the isolation process completed, the solution (liquor) was separated from the solids using a filter paper.

\section{Analysis of Lignin and Silica Concentrations of Liquor}

Lignin concentration of liquor was analyzed by UV-Vis Spectrophotometer (UV-1800 SHIMADZU) with a resolution of $1 \mathrm{~nm}$. Lignin concentration was done at the wavelength of $280 \mathrm{~nm} .{ }^{25}$ Silica concentration of liquor was analyzed by AAS (AA-6300 SHIMADZU). The analytical process was done using silica cathode lamp at the wavelength of $251.53 \mathrm{~nm}$. Burning gasses were using nitrous oxide and ethylene.

\section{Purification and Precipitation of Lignin}

Purification of lignin was executed by using microfiltration with the ceramic membrane. The ceramic membrane was supplied by Polymer and Membrane Research Center of Chemical Department of Universitas Muhammadiyah Purwokerto. Precipitation of lignin was carried out by adding $\mathrm{H}_{2} \mathrm{SO}_{4} 2 \mathrm{~N}$ until $\mathrm{pH}$ of 2 . The liquor was then stirred for 4 hours. The precipitated lignin was dried at the temperature of $60^{\circ} \mathrm{C}$ for 6 hours. Rice husk lignin (RHL) obtained was then characterized using Fourier Transform Infrared (FT-IR) spectrophotometer.

\section{Characterization Methods}

FT-IR spectrophotometer (SHIMADZU with DRS-8000) was used to analyze Fourier Transform Infrared spectroscopy using a $\mathrm{KBr}$ pellets. The $\mathrm{KBr}$ pellets consist of $300 \mathrm{mg} \mathrm{KBr}$ and $0.1 \mathrm{mg}$ fine powder of lignin sample. Scans were recorded from 400 to $4000 \mathrm{~cm}^{-1}$ at a resolution of $16 \mathrm{~cm}^{-1}$.

\section{Design Experiment}

The optimization of isolation of lignin from rice husk was using response surface methodology with central composite design (CCD). The range and level of independent process variables are shown in Table-1. The response of each variable and interaction of variables was evaluated using a quadratic polynomial model equation. The equation of quadratic polynomials is described in Equation-1:

$$
Y=\beta_{o}+\sum_{j=1}^{3} \beta_{j} X_{j}+\sum_{j=1}^{3} \beta_{j j} \beta_{j}^{2}+\sum_{i<j} \beta_{i j} X_{i} X_{j}
$$


The significance of each variable and interaction of variables was evaluated by P-value at the significance of $95 \%$. The analysis of variance (ANOVA) using Fisher F-test was used to assess the each model obtained. STATISTICA 6 was used to analysis the models.

Table-1: Range and level of independent process variables

\begin{tabular}{l|l|l|l|l|l}
\hline \multirow{2}{*}{ Variables $(\mathrm{X})$} & \multicolumn{4}{l}{ Range and levels } \\
\cline { 2 - 6 } & $-\alpha$ & -1 & 0 & +1 & $+\alpha$ \\
\hline Solvent/weight ratio $\left(\mathrm{X}_{1}\right), \mathrm{ml} / \mathrm{gr}$ & 7.32 & 8.00 & 9.00 & 10.00 & 10.68 \\
\hline $\mathrm{H}_{2} \mathrm{O}_{2}$ Concentration $\left(\mathrm{X}_{2}\right), \%$ & 0.66 & 1.00 & 1.50 & 2.00 & 2.34 \\
\hline $\mathrm{pH}\left(\mathrm{X}_{3}\right)$ & 10.16 & 10.50 & 11.00 & 11.50 & 11.84 \\
\hline
\end{tabular}

\section{Model Fitting Analysis}

\section{RESULTS AND DISCUSSION}

Analysis of Response Surface Methodology was done to study the influence of solid ratio, the concentration of hydrogen peroxide and $\mathrm{pH}$ of the solution on the concentration of lignin and silica of liquor. The design of experiment (DOE) of lignin extraction process is presented in Table-1. The research data used to assess the effect of process variables on the lignin and silica extracted are shown in Table-2. Table- 2 shows that the concentration of lignin of liquor is in the range from $0.828 \%$ to $1.855 \%$. On the other hand, the concentration of silica was found in value from $158.224 \mathrm{ppm}$ to $1946.217 \mathrm{ppm}$. The multiple regression analysis was applied to the experiment data. The correlation of response variable and the test variables are determined by the second-order polynomial equation according to the coded values as expressed by equation (2) and (3):

$$
\begin{aligned}
& Y_{L}=1.712436+0.410846 X_{3}-0.285710 X_{3}^{2} \\
& Y_{S i}=1155.619-585.963 X_{2}^{2}+654.454 X_{3}
\end{aligned}
$$

Where $\mathrm{Y}_{\mathrm{L}}$ is the lignin concentration of liquor and $\mathrm{Y}_{\mathrm{Si}}$ is the silica concentration of liquor calculated by the regression model, $\mathrm{X}_{1}, \mathrm{X}_{2}$, and $\mathrm{X}_{3}$ are the coded variables.

The observed and predicted value of the lignin concentration of liquor $\left(\mathrm{Y}_{\mathrm{L}}\right)$ and the silica concentration of liquor $\left(\mathrm{Y}_{\mathrm{Si}}\right)$ were examined and described in Figure-1 and Figure-2. This test was conducted to determine the suitability between the observed values and the predicted value.

The determination coefficients value $\left(\mathrm{R}^{2}\right)$ of 0.80178 and 0.79983 for $\mathrm{Y}_{\mathrm{L}}$ and $\mathrm{Y}_{\mathrm{Si}}$ show that the observed and predicted values have a good suitability.

The fit quality of the lignin concentration of liquor $\left(\mathrm{Y}_{\mathrm{L}}\right)$ and the silica concentration of liquor $\left(\mathrm{Y}_{\mathrm{Si}}\right)$ model was examined with analysis of variance (ANOVA) as described in Table-3 and Table-4. Table-3 presents that the calculated F-value of the lignin concentration of liquor at 30.6121 is indeed higher than that of $\mathrm{F}$ distribution table $(\mathrm{F}$-tabel $(0,95 ; 7,16)=3.4944)$ at $5 \%$ level of significance. It shows the relationship between process variables with the lignin concentration of liquor. Table-4 displays that the calculated F-value of the silica concentration of liquor at 25.51346 is indeed higher than that of $\mathrm{F}$ distribution table (F-tabel $(0,95 ; 7,16)=3.4944)$ at $5 \%$ level of significance. It shows also that the silica concentration of liquor influenced by the process variables.

Table-2: Lignin and silica concentration of liquor at various process variables

\begin{tabular}{c|c|c|c|c|c}
\hline Run & $\begin{array}{c}\text { Solvent/solid ratio }\left(\mathrm{X}_{1}\right), \\
\mathrm{ml} / \mathrm{gr}\end{array}$ & $\begin{array}{c}\mathrm{H}_{2} \mathrm{O}_{2} \\
\text { Concentration } \\
\left(\mathrm{X}_{2}\right), \%\end{array}$ & $\mathrm{pH}\left(\mathrm{X}_{3}\right)$ & $\begin{array}{c}\text { Lignin } \\
\text { concentration of } \\
\text { liquor }\left(\mathrm{Y}_{\mathrm{L}}\right), \%\end{array}$ & $\begin{array}{c}\text { Silica } \\
\text { concentration of } \\
\text { liquor }\left(\mathrm{Y}_{\mathrm{Si}}\right), \mathrm{ppm}\end{array}$ \\
\hline 1 & $8.00(-1)$ & $1.00(-1)$ & $10.50(-1)$ & 1.576 & 907.072 \\
\hline 2 & $8.00(-1)$ & $1.00(-1)$ & $11.50(+1)$ & 1.576 & 934.457 \\
\hline 3 & $8.00(-1)$ & $2.00(+1)$ & $10.50(-1)$ & 1.524 & 774.013 \\
\hline 5 & $8.00(-1)$ & $2.00(+1)$ & $11.50(+1)$ & 1.629 & 1396.217 \\
\hline 5 & $10.00(+1)$ & $1.00(-1)$ & $10.50(-1)$ & 0.828 & 226.563 \\
\hline \multicolumn{5}{|c}{409}
\end{tabular}


RASĀYAN J. Chem.

Vol. 10 | No. 2 |407 - 414 | April - June | 2017

\begin{tabular}{c|c|c|c|c|c}
\hline 6 & $10.00(+1)$ & $1.00(-1)$ & $11.50(+1)$ & 1.454 & 991.530 \\
\hline 7 & $10.00(+1)$ & $2.00(+1)$ & $10.50(-1)$ & 0.974 & 352.385 \\
\hline 8 & $10.00(+1)$ & $2.00(+1)$ & $11.50(+1)$ & 1.454 & 1209.046 \\
\hline 9 & $7.32(-\alpha)$ & $1.50(0)$ & $11.00(0)$ & 1.629 & 1089.145 \\
\hline 10 & $10.68(+\alpha)$ & $1.50(0)$ & $11.00(0)$ & 1.629 & 1799.836 \\
\hline 11 & $9.00(0)$ & $0.66(-\alpha)$ & $11.00(0)$ & 1.454 & 158.224 \\
\hline 12 & $9.00(0)$ & $2.34(+\alpha)$ & $11.00(0)$ & 1.629 & 728.125 \\
\hline 13 & $9.00(0)$ & $1.50(0)$ & $10.16(-\alpha)$ & 0.907 & 639.474 \\
\hline 14 & $9.00(0)$ & $1.50(0)$ & $11.84(+\alpha)$ & 1.855 & 1946.217 \\
\hline 15 & $9.00(0)$ & $1.50(0)$ & $11.00(0)$ & 1.629 & 1205.263 \\
\hline 16 & $9.00(0)$ & $1.50(0)$ & $11.00(0)$ & 1.629 & 882.237 \\
\hline 17 & $9.00(0)$ & $1.50(0)$ & $11.00(0)$ & 1.855 & 1339.474 \\
\hline
\end{tabular}

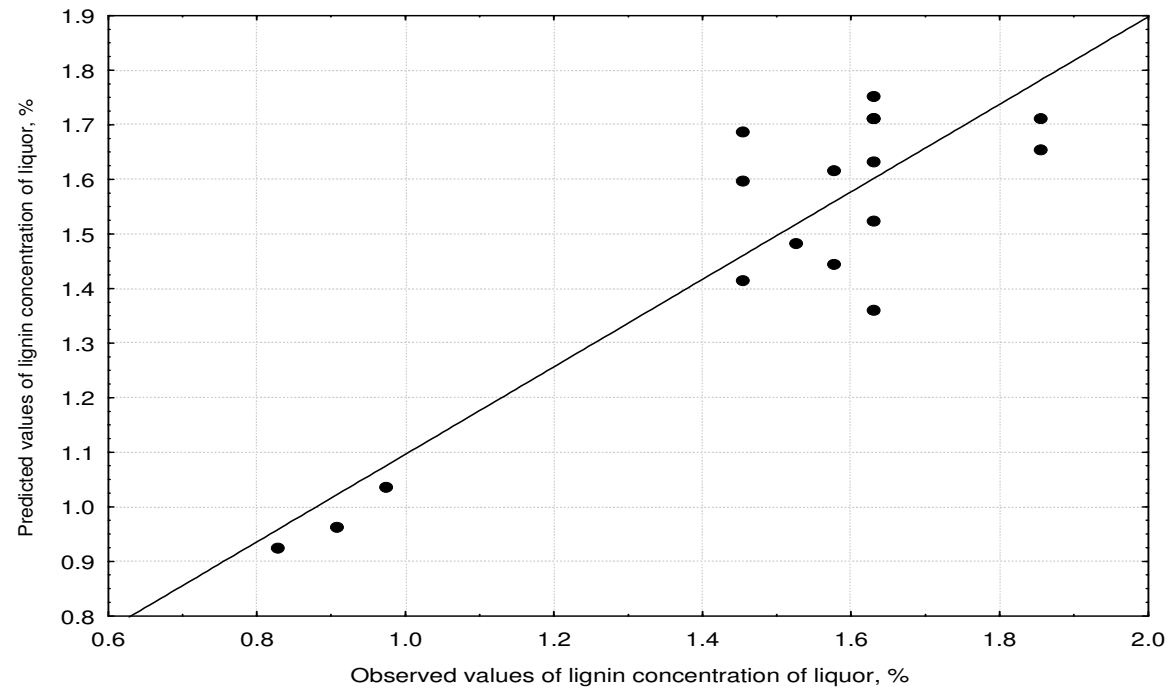

Fig.-1: Model suitability of lignin concentration of liquor $\left(\mathrm{R}^{2}=0.80178\right)$

Table-3: ANOVA results for the lignin concentration of liquor model

\begin{tabular}{c|c|c|c|c}
\hline Source & Sum of square & $\begin{array}{c}\text { Degree } \\
\text { of freedom }\end{array}$ & Mean Square & F-value \\
\hline SS regression & 1.2523 & 9 & 1.2523 & 30.6121 \\
\hline SS error & 0.2863 & 7 & 0.040900 & \\
\hline SS total & 1.4447 & 16 & & \\
\hline $\mathrm{R}^{2}$ & 0.80178 & & & \\
\hline
\end{tabular}

Table-4: ANOVA results for silica lignin concentration of liquor model

\begin{tabular}{c|c|c|c|c}
\hline Source & Sum of square & $\begin{array}{c}\text { Degree } \\
\text { of freedom }\end{array}$ & Mean Square & F-value \\
\hline SS regression & 2844461 & 9 & 2844461 & 25.51346 \\
\hline SS error & 780420 & 7 & 111489 & \\
\hline SS total & 3898696.68 & 16 & & \\
\hline $\mathrm{R}^{2}$ & 0.79983 & & & \\
\hline
\end{tabular}

\section{Effect of Process Variables}

Tabel-5 and Table-6 illustrate the effect of variables on lignin and silica concentration of liquor. Based on Table-5, it can be seen that the main factor for lignin extraction using AHP is $\mathrm{pH}$ of the mixture. The pvalue for the linear and quadratic coefficient is below 0.05 . While the solvent to solid ratio and $\mathrm{H}_{2} \mathrm{O}_{2}$ concentration are not significant ( $\mathrm{p}$-value $>0.05$ ). 
RASĀYAN J. Chem.

Vol. 10 | No. 2 | 407 - 414 | April - June | 2017

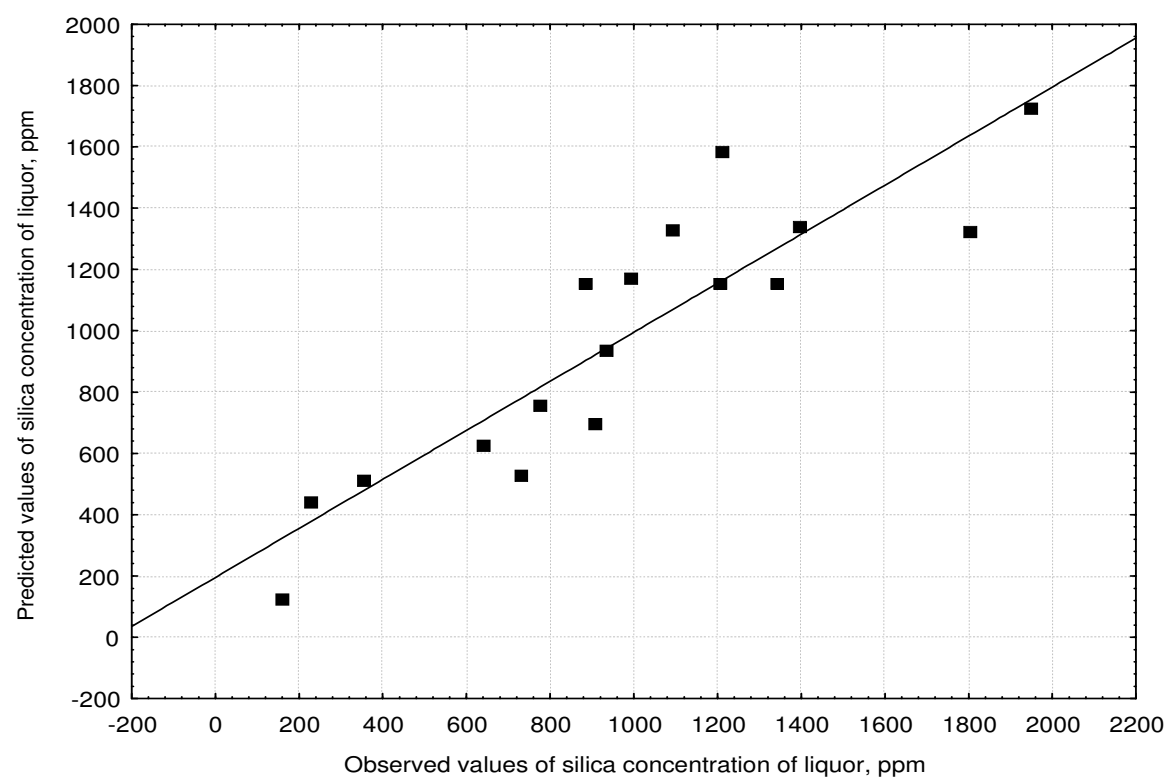

Fig.-2: Model suitability of silica concentration of liquor $\left(R^{2}=0.79983\right)$

Table-5: Effect estimates of variables on lignin concentration of liquor

\begin{tabular}{c|c|c|c}
\hline Factors & Effect & P-value & Assignment \\
\hline Intercept & 1.712436 & 0.000002 & \\
\hline Solvent/solid ratio, $\mathrm{X}_{1}(\mathrm{~L})$ & -0.233351 & 0.070485 & $\mathrm{~ns}$ \\
\hline Solvent/solid ratio, $\mathrm{X}_{1}(\mathrm{Q})$ & -0.110450 & 0.389766 & $\mathrm{~ns}$ \\
\hline $\mathrm{H}_{2} \mathrm{O}_{2}$ concentration, $\mathrm{X}_{2}(\mathrm{~L})$ & 0.064303 & 0.575358 & $\mathrm{~ns}$ \\
\hline $\mathrm{H}_{2} \mathrm{O}_{2}$ concentration, $\mathrm{X}_{2}(\mathrm{Q})$ & -0.172121 & 0.196177 & $\mathrm{~ns}$ \\
\hline $\mathrm{pH}, \mathrm{X}_{3}(\mathrm{~L})$ & 0.410846 & 0.007137 & $\mathrm{~s}$ \\
\hline $\mathrm{pH}, \mathrm{X}_{3}(\mathrm{Q})$ & -0.285710 & 0.049503 & $\mathrm{~s}$ \\
\hline $\mathrm{X}_{1}$ by $\mathrm{X}_{2}$ & 0.036433 & 0.806247 & $\mathrm{~ns}$ \\
\hline $\mathrm{X}_{1}$ by $\mathrm{X}_{3}$ & 0.250207 & 0.123693 & $\mathrm{~ns}$ \\
\hline $\mathrm{X}_{2}$ by $\mathrm{X}_{3}$ & -0.010150 & 0.945410 & $\mathrm{~ns}$ \\
\hline $\mathrm{R}$-sqr & 0.80178 & & \\
\hline Adj. & 0.5439 & & \\
\hline
\end{tabular}

$\mathrm{s}=($ significant $) ; \mathrm{ns}=($ not significant $)$

Table- 6 shows that the two factors affecting the silica extracted on the lignin extraction of rice husk using AHP that are the $\mathrm{H}_{2} \mathrm{O}_{2}$ concentration and $\mathrm{pH}$ of the mixture. The p-value for quadratic coefficient of $\mathrm{H}_{2} \mathrm{O}_{2}$ concentration is 0.02279 ( $\mathrm{p}$-value < 0.05). And, p-value for linear coefficient of $\mathrm{pH}$ is 0.00849 ( $\mathrm{p}$-value < $0.05)$.

Table-6: Effect estimates of variables on silica concentration of liquor

\begin{tabular}{c|c|c|c}
\hline Factors & Effect & P-value & Assignment \\
\hline Intercept & 1155.619 & 0.000539 & \\
\hline Solvent/solid ratio, $\mathrm{X}_{1}(\mathrm{~L})$ & -5.419 & 0.976914 & $\mathrm{~ns}$ \\
\hline Solvent/solid ratio, $\mathrm{X}_{1}(\mathrm{Q})$ & 122.075 & 0.558775 & $\mathrm{~ns}$ \\
\hline $\mathrm{H}_{2} \mathrm{O}_{2}$ concentration, $\mathrm{X}_{2}(\mathrm{~L})$ & 238.781 & 0.227924 & $\mathrm{~ns}$ \\
\hline $\mathrm{H}_{2} \mathrm{O}_{2}$ concentration, $\mathrm{X}_{2}(\mathrm{Q})$ & -585.963 & 0.021525 & $\mathrm{~s}$ \\
\hline $\mathrm{pH}, \mathrm{X}_{3}(\mathrm{~L})$ & 654.454 & 0.008491 & $\mathrm{~s}$ \\
\hline $\mathrm{pH}, \mathrm{X}_{3}(\mathrm{Q})$ & 14.846 & 0.942588 & $\mathrm{~ns}$ \\
\hline $\mathrm{X}_{1}$ by $\mathrm{X}_{2}$ & 3.660 & 0.988066 & $\mathrm{~ns}$ \\
\hline $\mathrm{X}_{1}$ by $\mathrm{X}_{3}$ & 243.010 & 0.337604 & $\mathrm{~ns}$ \\
\hline
\end{tabular}




\begin{tabular}{c|c|c|c}
\hline $\mathrm{X}_{2}$ by $\mathrm{X}_{3}$ & 171.628 & 0.490862 & $\mathrm{~ns}$ \\
\hline $\mathrm{R}$-sqr & 0.79983 & & \\
\hline Adj. & 0.54246 & & \\
\hline
\end{tabular}

$\mathrm{s}=($ significant $) ; \mathrm{ns}=($ not significant $)$

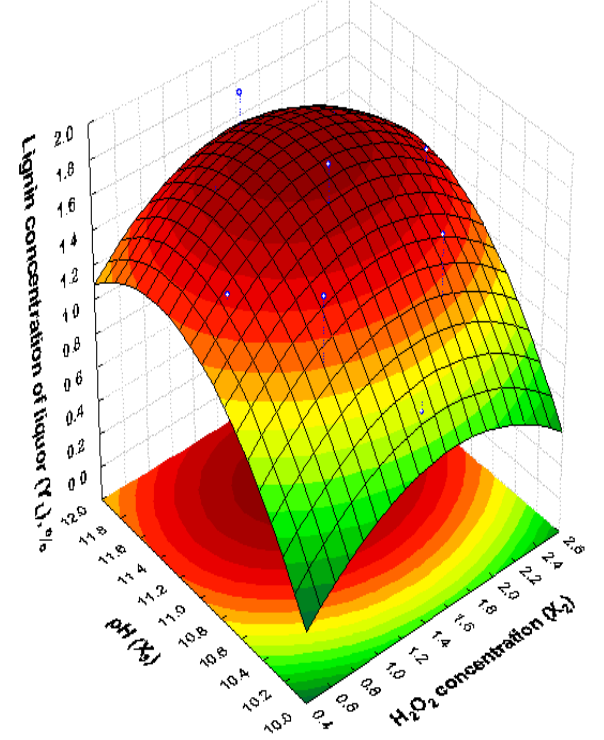

( a )

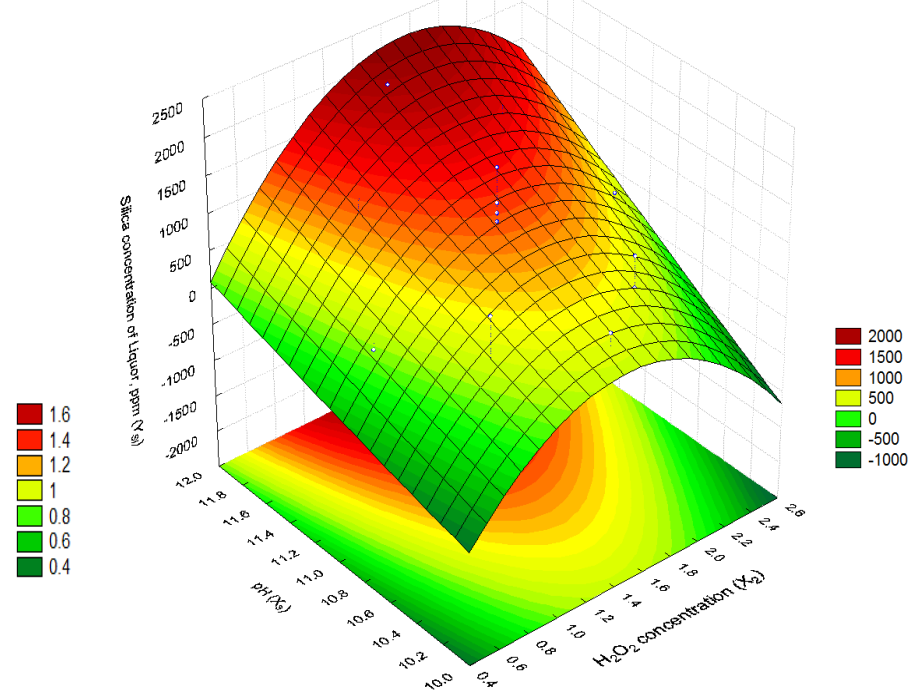

( b )

Fig.-3: Three-dimensional response surface: (a) silica concentration of liquor; (b) silica concentration of liquor

Table-7 shows that the optimum conditions for lignin extraction from rice husk using AHP are at the solvent to solid ratio of 8.55 , the $\mathrm{H}_{2} \mathrm{O}_{2}$ concentration of $1.56 \%$ and $\mathrm{pH}$ of 11.26 . At optimum condition, the amount of lignin extraction is $1.7939 \%$. Figure- 3 shows the lignin and silica concentration of liquor at various $\mathrm{pH}$ and $\mathrm{H}_{2} \mathrm{O}_{2}$ concentration. At the optimum condition, the amount of silica extracted is 1,631.80 ppm.

Table-7: Critical value of lignin extraction using AHP

\begin{tabular}{c|c|c|c}
\hline Factors & $\begin{array}{c}\text { Observed } \\
\text { minimum }\end{array}$ & $\begin{array}{c}\text { Critical } \\
\text { value }\end{array}$ & $\begin{array}{c}\text { Observed } \\
\text { maximum }\end{array}$ \\
\hline Solvent/solid ratio, $\mathrm{X}_{1}$ & 7.31821 & 8.55564 & 10.68179 \\
\hline $\mathrm{H}_{2} \mathrm{O}_{2}$ concentration, $\mathrm{X}_{2}$ & 0.65910 & 1.56219 & 2.34090 \\
\hline $\mathrm{pH}, \mathrm{X}_{3}$ & 10.15910 & 11.26111 & 11.84090 \\
\hline
\end{tabular}

\section{FT-IR Characteristics of Pure Lignin}

Figure-4 shows the spectra of pure rice husk lignin obtained. The band between $3330-3400 \mathrm{~cm}^{-1}$ is a typical of hydroxyl groups $(\mathrm{O}-\mathrm{H}$ stretch) in phenolic and aliphatic structures. The peak at 2924.09 and $2854.65 \mathrm{~cm}^{-1}$ indicated a sp ${ }^{3} \mathrm{C}-\mathrm{H}$ stretching in methyl $\left(-\mathrm{CH}_{3}\right)$, methylene $\left(=\mathrm{CH}_{2} /-\mathrm{CH}_{2}-\right)$ and methoxy ($\mathrm{OCH}_{3}$ ) groups. ${ }^{21}$ In the carbonyl/carboxyl region, a weak band is found at $1720.50 \mathrm{~cm}^{-1}$, originating from unconjugated carbonyl/carboxyl stretching ${ }^{26}$. The band at $1635.64 \mathrm{~cm}^{-1}$ confirms a $\mathrm{C}=\mathrm{O}$ stretching in conjugated p-substituted aryl ketones ${ }^{21}$. The range band of p-substituted aryl ketones is found at 1670$1640 \mathrm{~cm}^{-1}$. An Aromatic skeleton vibration is showed at the band of $1512.19 \mathrm{~cm}^{-1}$.

The band at $1396.48 \mathrm{~cm}^{-1}$ is a typical aromatic skeleton vibration combined with $\mathrm{C}-\mathrm{H}$ in plane deformations, while $1365.80 \mathrm{~cm}^{-1}$ is of aliphatic $\mathrm{C}-\mathrm{H}$ stretching in $\mathrm{CH}_{3}$ (not $-\mathrm{OCH}_{3}$ ) and phenolic $-\mathrm{O}-\mathrm{H}$. The band at $1211.00 \mathrm{~cm}^{-1}$ shows $\mathrm{C}-\mathrm{C}$ plus $\mathrm{C}-\mathrm{O}$ plus $\mathrm{C}=\mathrm{O}$ stretching $(\mathrm{G}$ condensed $>\mathrm{G}$ etherified, typical of $\mathrm{G}$ units). ${ }^{21}$ FT-IR spectra indicate the spectral features of GSH type lignin that are the band at 1134 and $864.11 \mathrm{~cm}^{-1} 27$. The aromatic $\mathrm{C}-\mathrm{H}$ deformation at $1064.71 \mathrm{~cm}^{-1}$ appears as aromatic $\mathrm{C}-\mathrm{H}$ in plane deformation $(\mathrm{G}>\mathrm{S})$ plus $\mathrm{C}-\mathrm{O}$ deformation in primary alcohols plus $\mathrm{C}=\mathrm{O}$ stretching (unconjugated). ${ }^{21}$ 
Commonly, the RHL obtained has similar characteristics with lignin from another biomass source. However, based on FT-IR spectra, the RHL was found having specific characteristics at the band of 2360.78 and $2075.41 \mathrm{~cm}^{-1}$. The band between $2100-2360 \mathrm{~cm}^{-1}$ is a typical Si-H bond. ${ }^{28-30}$ It means that the lignin still containing Silica. Singh and Dhepe ${ }^{21}$ reported the FT-IR characteristics of RHL extracted by the organosolv process. Their report showed no peak at the band of 2360.78 and $2075.41 \mathrm{~cm}^{-1}$

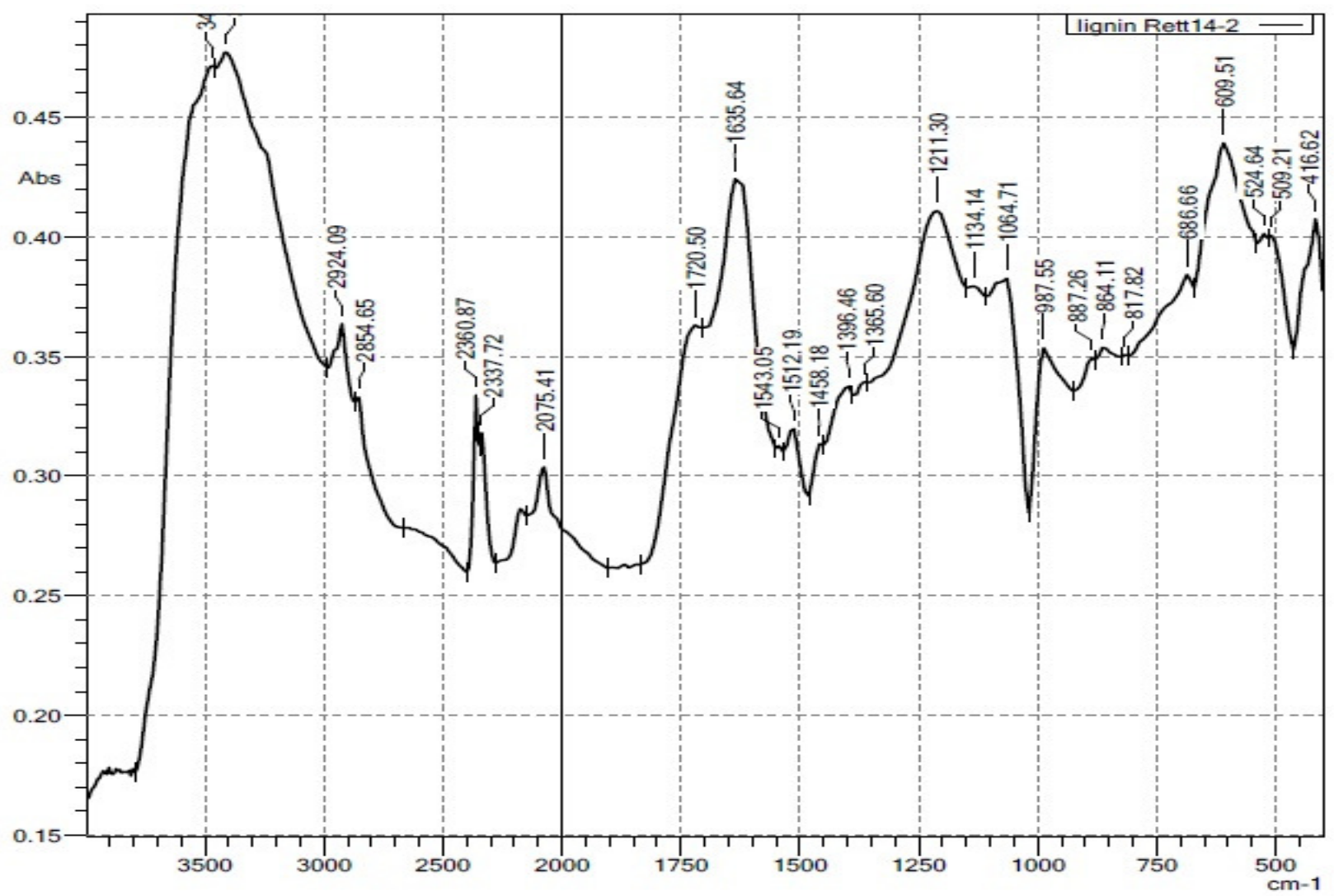

Fig.-4: FT-IR spectra of pure rice husk lignin (RHL)

\section{CONCLUSION}

Alkaline hydrogen peroxide (AHP) is of oxidative solvents. AHP solvent is effective enough to raise the yield of lignin obtained from rice husk. Optimization of process variables was success done by response surface methodology with the central composite design. The optimum conditions for lignin extraction from rice husk using AHP are at the solvent to solid ratio of 8.55 , the $\mathrm{H}_{2} \mathrm{O}_{2}$ concentration of $1.56 \%$ and $\mathrm{pH}$ of 11.26. At optimum condition, the amount of lignin extraction is $1.7939 \%$. RHL obtained has similar characteristics with lignin from another biomass source. However, based on FT-IR spectra, RHL has specific characteristics that are at the band of 2360.78 and $2075.41 \mathrm{~cm}^{-1}$. The band between 2100 and $2360 \mathrm{~cm}^{-1}$ is a typical $\mathrm{Si}-\mathrm{H}$ bond.

\section{ACKNOWLEDGEMENT}

This study was supported by dissertation scholarship program of LPDP, Ministry of Finance of Indonesia.

\section{REFERENCES}

1. S. Y. Adaganti, B. M. Kulkarni, G. P. Desai, and S. Shanmukhappa, Int. J. Curr. Eng. Technol., 4(2), 542(2014).

2. K. Ross and G. Mazza, Int. J. Mol. Sci., 11(10), 4035(2010).

3. H. Zhang, X. Zhao, X. Ding, and H. Lei, Z. Wang, Bioprocess Biosyst. Eng., 36(8), 1149 (2013). 
4. Y. P. Chen and X. S. Cheng, J. For. Res., 19(2), 159(2008).

5. M. Oghbaie, S. A. MIrshokraie, A. H. Massoudi, and T. Partovi, Mod. Chem., 2(5), 36(2014).

6. J. Rencoret, P. Prinsen, A. Gutiérrez, Á. T. Martínez, and J. C. del Río, J. Agric. Food Chem., 63(2), 603(2015).

7. A. A. Shamsuri and D. K. Abdullah, Oxid. Commun., 35(3), 767(2012).

8. J. M. Fang, R. C. Sun, and J. Tomkinson, Cellulose, 7, 87(2000).

9. C.-Z. Chen, M.-F. Li, Y.-Y. Wu, and R.-C. Sun, Cellul. Chem. Technol., 49(2), 153(2015).

10. M. M. Ibrahim, F. A. Agblevor, and W. K. El-Zawawy, BioResources, 5(1), 397(2010).

11. J. K. Ko, Y. Kim, E. Ximenes, and M. R. Ladisch, Biotechnol. Bioeng., 112(2), 252(2014).

12. S. Machmudah, H. Kanda, M. Sasaki, and M. Goto, Eng. J., 19(4), 25(2015).

13. J. K. Kurian, Y. Gariepy, V. Orsat, and G. S. V. Raghavan, Bioresour. Bioprocess., 2(30), 1(2015).

14. J. M. Gould, Biotechnol. Bioeng., 27, 225-231 (1985).

15. Y. L. Han, J. Gao, Y. Y. Yin, Z. Y. Jin, X. M. Xu, and H. Q. Chen, Carbohydr. Polym., 151, 381(2016).

16. H. L. Jiang, J. L. Yang, and Y. P. Shi, Ultrason. Sonochem., 34, 325(2017).

17. E. Karacabey and G. Mazza, Food Chem., 119(1), 343(2010).

18. C. Liyana-Pathirana and F. Shahidi, Food Chem., 93(1), 47(2005).

19. D. R. Pompeu, E. M. Silva, and H. Rogez, Bioresour. Technol., 100(23), 6076(2009).

20. M. R. Karim, M. F. M. Zain, and M. Jamil, World Appl. Sci. J., 19(10), 1501(2012).

21. S. K. Singh and P. L. Dhepe, Bioresour. Technol., 221, 310(2016).

22. N. Lokeswari, Rasayan J. Chem., 3(1), 172(2010).

23. I. Rahmi, H. Suyani, R. Zein, and A. Alif, Rasayan J. Chem., 9(1), 8(2016).

24. Y. Garnida, Y. Taufik, and T. Widiantara, Rasayan J. Chem., 9(4), 762(2016).

25. R. C. Sun, J. M. Fang, and J. Tomkinson, Ind. Crops Prod., 12(2), 71(2000).

26. C. G. Boeriu, D. Bravo, R. J. A. Gosselink, and J. E. G. Van Dam, Ind. Crops Prod., 20(2), 205(2004).

27. R. Sun and J. Tomkinson, Ultrason. Sonochemistry, 9, 85(2002).

28. L. Gao, N. P. Lu, L. G. Liao, L. Ji, and Z. X. Cao, J. Phys. D. Appl. Phys., 45(33), 335104 (2012).

29. J. P. Bell, J. E. Cloud, J. Cheng, C. Ngo, S. Kodambaka, A. Sellinger, S. K. R. Williams, and Y. Yang, $R S C A d v ., 4(93), 51105(2014)$.

30. I. Leontis, A. Othonos, and A. G. Nassiopoulou, Nanoscale Res. Lett., 8(1), 383 (2013).

[RJC-1667/2017] 